\title{
THE CENTRAL BANKS' POLICY RESPONSE TO COVID-19 PANDEMIC
}

Keywords:

Central Banks; monetary policy; corona virus; pandemic crisis

Author:

Dr. Branka Topić-Pavković is an Assistant Professor at the Faculty of Economics of the University of Banja Luka

Correspondence: branka.topic-pavkovic@ ef.unibl.org

Field:

Fiscal and Monetary Economics

DOI:

10.5937/politeia0-26720

Paper received on: 23.05.2020.

Paper accepted for publishing on:

\section{Summary}

During the past few months, the world has been battling an unexpected and invisible threat. It has challenged all aspects of life in dealing with economic, humanitarian, and social consequences. At the moment, the economic impacts of the corona crisis are still a puzzle, but the fact is that the largest crisis in the recent history caused by a pandemic will lead to a global recession. In times of crisis, a policy-mix strategy is necessary and implies the inclusion of respective Central Banks in providing adequate measures of monetary policy for economic and financial recovery.

The aim of this paper is to identify and analyse measures taken by respective Central Banks in order to mitigate the damage caused by the virus crisis and help national economies in recovery. Reactivation of non-standard measures applied in the previous financial crisis shows that the standard instruments and targets of such institutions are insufficient in emergency circumstance.

The comparative analysis conducted will show how Central Banks of the largest economies and the region responded to the corona virus challenge, with particular reference to the Central Bank of Bosnia and Herzegovina. The results show that Central Banks opted for unconventional monetary policy measures reflected in quantitative easing, zero interest rates, and swap lines in order to alleviate the negative effects of the emerging crisis. Exceptional measures will be needed to ensure recovery in response to the coronavirus and the rapid deterioration of the global economy. The specificity of the monetary arrangement in Bosnia and Herzegovina has once again proved to be a constraint in the implementation of economic policy measures in extraordinary circumstances.

02.07.2020 


\section{INTRODUCTION}

The COVID-19 pandemic crisis is an unprecedented shock that affected the world and the global economy. As countries shift to a stay-at-home mode to slow and stop the spread of the virus, governments and societies are dealing with the human, social and economic costs. Through history, markets have faced asymmetric shocks with different effects on different countries, but lately there has been no such case of symmetrical shock. Therefore, the recovery of global economy forecasts are quite uncertain both in the assessment of the damage and the length of the recovery. The rapid decline in production and international trade the coronavirus has caused drastically affected the global economic outlook. States have been imposed new responsibilities in finding solutions to mitigate the damage caused by the virus crisis, as well as to take prompt and adequate recovery measures. Most of the crisis packages in supporting the national economies relate to helping people who lost their jobs, the liquidity of the banking and financial system as well as securing funding for businesses.

The estimated negative economic effects are reflected in unemployment increases and lowered incomes, consequently demand decreases, production difficulties, volatility of global financial markets, banks illiquidity, problems with credit supply in the economy, etc. Therefore, the public authorities will, once again, play a decisive role in mitigating the economic damage, and that also applies to the CB. In this paper we will explain how the $\mathrm{CB}$ has responded to these challenges, and how to provide adequate measures in alleviating the economic and financial fallout from the pandemic, supporting firms and households. The traditional, main objective of most CBs is to provide a stable currency, financial stability and at the same time an economic base for investment and business. An emergency circumstance requires extraordinary measures, as the previous 2008 crisis already showed. In terms of the role and function of CBs, this meant that CBs had to consider uncommon stabilization measures and take concrete steps to help national economies.

As the most commonly identified, the main tool of conventional monetary policy is the control of a short-term interest rate: changes in this policy rate and the public's expectations of its future settings, affected financial conditions (i.e. the availability and cost of funding) and, further down the transmission channel, affected the macroeconomic (i.e. aggregate spending, output and inflation). At the operational level, CBs' frameworks were generally characterised by reserve scarcity, with CBs using relatively small shifts in the supply of reserves to steer the policy rate towards its target. Open market operations were conducted with a pre-specified set of counterparties (Potter and Smets, 2019: 8). The unconventional monetary policy tools helped the CBs in the circumstances caused by the previous crisis and the inevitable economic decline. The most commonly applied measures included new CB lending operations, negative interest rate policies, forward guidance and asset purchase programmes.

The aim of this paper is to identify and analyse the actions taken by CBs as responses to the COVID-19 pandemic. We will observe CBs measures of the largest economies, countries in the region and the $\mathrm{CB}$ of Bosnia and Herzegovina. Exceptional measures will be needed to ensure recovery in response to the coronavirus and the rapid deterioration of global economic development. The consequential actions of most of the CBs may be 
summarised in the following forms: reducing interest rates, free lending to banks and other financial institutions and supporting financial institutions to extend credit especially for companies affected by the crisis. In reviewing the most important decisions of CBs, we will also take into account the specificities of the $\mathrm{CB}$ in Bosnia and Herzegovina.

\section{LITERATURE REVIEW}

During the stable economic growth and with no market turbulence, monetary policy represents an efficient tool for macroeconomic stabilisation while fiscal policy becomes more focused on the medium-term problem of growth and efficiency. Extensive economic literature indicates that most CBs followed similar monetary policy primarily keeping inflation close to a target level and with some differences in their operational frameworks. Ayuso, J. and Repullo, R. (2003) and Bindseil, U. and Nyborg, K. (2008) identified credit open market operations by the $\mathrm{CB}$ as the standard tool to steer liquidity conditions. Ho, C. (2008), Blanchard, O. et al. (2014) and Sellin, P. and Sommar, P. A. (2014) recognise a shortterm interest rate as the best operational target. On the other hand, reserve requirements can be seen as a daily tool for solving liquidity shocks without daily open market operations. Yet here different decisions are noticed, depending on the specifics of the given country. A similar situation is found in the case of financing government debt with CBs assets.

Literature during the crisis and aftermath in economic studies have shown, the economic cycles of expansion and crisis are followed by various $\mathrm{CB}$ measures that adjust to new market circumstances. Findings of Fecht et al show that distribution of liquidity across banks leads to more aggressive bidding and higher prices paid for liquidity. The price a bank pays depends on its individual liquidity position as well as the distribution of liquidity across banks, which implies that large banks have better access to the interbank market for liquidity than smaller banks. Unlike conventional monetary policy, unconventional measures targeted something other than short-term interest rates and that implies to: term spreads (or, equivalently, long-term risk free rates); liquidity and credit spreads (or, equivalently, interest rates on various non-risk free instruments); financial stability for the sake of supporting the monetary policy transmission mechanism (Bindseil, 2016). In dealing with the global financial crisis CBs introduced new policy instruments and made changes to their monetary policy (Meade, E. et al 2015; McAndrews, 2015; Nakashima, K. et al., 2017; etc). The most commonly applied measures included new CB lending operations, negative interest rate policies, forward guidance and asset purchase programmes. Brunnermeier and Koby (2018) discuss how the reversal rate relates to bank profits and capital position. McAndrews (2015) points out how the structure of financial markets affects the effective lower bound. Some CBs had used unconventional measures before the 2008 crisis. For instance, forward guidance, which can be seen as CB's transparency requirement. Forward guidance served to clarify CBs' intentions with respect to future policy rate settings and was used to enhance the clarity of policymakers' strategic intentions (Poter and Smats, 2019: 3).

Literature on the behaviour of $\mathrm{CBs}$ in the wake of the corona pandemic is still in its early stage, and in further analysis we will point out some novel findings. 


\section{METHODOLOGICAL FRAMEWORK OF RESEARCH}

Empirical analysis comprises CBs of the largest economies in their response to the COVID-19 pandemic. Within a two months period the timeline shows the measures taken by the CBs of the main world economies. We will comprise actions of FED (US FEDeral Reserve) and the ECB (ECB) and show similarities and differences in responses. Also we find it important to present actions of the Bank of Japan (BOJ) and the People's Bank of China (PBOC). We monitored key measures and actions undertaken by these CBs, taking into account the specifics of each CB.

Comparative analysis review trends in CBing of countries in the region, as well as key policy responses in Bosnia and Herzegovina. Particular emphasis in the analysis is given to the constraints of monetary policy instruments in the arrangement of the currency board. In this comparative analysis besides a primary data base from the official websites of the observed CBs and financial institutions, the author used a secondary data base, which is partly summarised in a Peterson Institute for International Economics report ${ }^{1}$.

\section{THE LARGEST ECONOMIES CBS ACTIONS}

Besides the obvious economic reason in considering the $\mathrm{CBs}$ of the largest economies, the reason also lies in the fact that a coordinated and comprehensive strategy is necessary to deal with emergency needs and to encourage global economic activity. As an important part of the economic policy responsible for adequate and rapid measures to mitigate the overall damage, the CBs must be equally involved in the recovery.

The ECB introduced a new Pandemic Emergency Purchase Programme with the main objective to provide relief to banks in boosting loans to businesses and households, as well as to support production and employment. During March 2020 the amount of $€ 750$ billion was released, in addition to the $€ 120$ billion decided earlier. Together this amounts to $7.3 \%$ of the euro area GDP (ECB, 2020). A similar action was taken by the FED in the US, which includes the purchase of $\$ 500$ billion in T-bills and $\$ 200$ billion in mortgage-backed securities to support the functioning of these marketplaces. With the advent of crises, certain differences in the role and strength of transmission mechanisms have come to light. The main reason for the differences in transmission mechanisms is the characteristics of individual countries, so the importance of monetary channels is different in individual countries. The development of the financial sector, the openness of the economy and certain structural differences are just some of the variables that determine the impact of monetary measures in individual economies.

1 See Collins, C. G., and Gagnon, J. E. (2020) for a detailed timeline 
Table 1. CBs responses to the COVID-19 pandemic

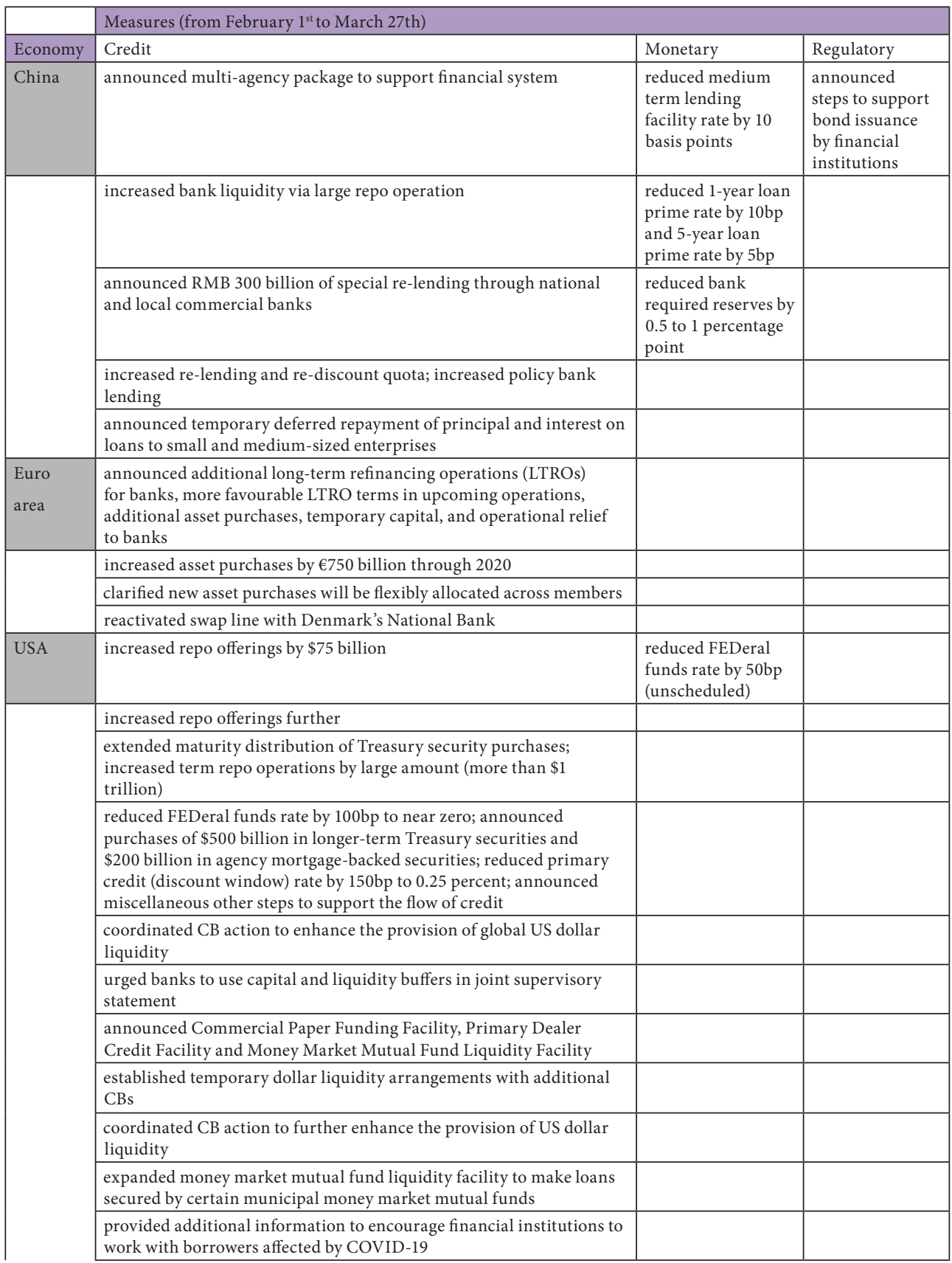




\begin{tabular}{|l|l|l|l|}
\hline \begin{tabular}{|l|l|} 
announced Treasury purchases and agency MBS in "amounts needed"; \\
included commercial MBS in purchases; announced measures to \\
provide a combined \$300 billion in new financing, including \$30 \\
billion from the Exchange Stabilisation Fund (ESF); established \\
Primary and Secondary Market Corporate Credit Facilities; \\
established Term Asset-Backed Securities Loan Facility enabling asset- \\
backed securities backed by student loans, auto loans, credit card loans, \\
loans guaranteed by the Small Business Administration, and certain \\
other assets; expanded Money Market Mutual Fund Liquidity and \\
Commercial Paper Funding Facility
\end{tabular} & & & \\
\cline { 2 - 4 } & $\begin{array}{l}\text { working with other financial supervisors, communicated to banks } \\
\text { various regulatory actions to encourage lending }\end{array}$ & & \\
\hline JAPAN & offered unspecified "ample" liquidity for repo market & \\
\hline & $\begin{array}{l}\text { increased purchases of ETFs, JREITs, and loans secured by } \\
\text { commercial paper and corporate bonds }\end{array}$ & & \\
\hline & announced minor measures to maintain stability or repo market & & \\
\hline
\end{tabular}

Source: adapted by the author, from Collins, G.C. \& Gagnon, E.J. (2020). A timeline of CB responses to the COVID-19 pandemic. Accessed on April 2020-04-11: https://www.piie.com/ blogs/realtime-economic-issues-watch/timeline-central-bank-responses-covid-19-pandemic

The analysis in the presented timeline summarises measures in three broad areas including credit, monetary and regulatory aspect of actions. These measures have the same goal in supporting the national and global economy, helping the economy absorb the shock of the current crisis, keeping borrowing affordable, increasing banks' lending capacity, supporting access to credit for firms and households and preserving financial stability through international cooperation.

The measure of quantitative easing is the most obvious unconventional monetary policy instrument specified. This measure became widely used as a response to the easing of the crisis in 2008. The original form was applied in Japan and then taken over by other major economies. Conventional monetary policy operates by affecting short-term interest rates through open market operations. Buying or selling securities from the banking system, they have influence on the level of reserves that banks hold in the system. In normal times, these fluctuations in the volume of reserves are merely a by-product and are not a focus or target of policy itself. Instead, fluctuations in reserves are a means to achieve desired changes in interest rates. The phrase 'quantitative easing' was introduced to signal a shift in focus towards targeting quantity variables (Joyce, et al., 2012: 274).

According to Gambetti, L. and Musso, A. (2017) the mechanism of the impact of the mass purchase of bonds and the growth of the ECB's assets on the defined goals is based on the transmission mechanisms of the banking market and modern portfolio theory and portfolio diversification. The purchase of bonds from banks increases the money supply, while interest rates in these conditions fall, and at the same time the yields on issued securities. In the conditions of higher money supply, indebted individuals need a smaller amount of money to repay existing debts, and new loans become 'cheaper', and as a result, investment grows as well as spending, lending and employment. The expansion of the economy and consumption also encourages the growth of the general price level.

The method of Zero Interest Rate Policy (ZIRP) is also available to the CBs. ZIRP is a "zero nominal interest rate" policy implemented by the CBs of the United States, Japan, the United Kingdom and several EU member states, in order to combat deflation in post-crisis years and ensure faster economic recovery by 
maintaining external competitiveness. ZIRP is a method of stimulating growth by lowering the level of the nominal interest rate to a positive level close to zero, or zero. By adopting this policy, the $\mathrm{CB}$ actually renounces conventional monetary measures, as instruments of monetary policy, because they become ineffective in the stated conditions. NIRP - a policy of negative nominal interest rates (below zero) is a more radical measure of monetary policy that has been recorded only a few times in history, in which the CB seeks to provide additional impulse to the economy during contractions, charging interest on deposits by commercial banks held in a $\mathrm{CB}$ account.

Secondly, in a crisis, most CBs become last resort lenders. And in this case we can see that the largest CBs are maintaining liquidity by lending freely to banks, other financial institutions, foreign $\mathrm{CBs}$, and even nonfinancial institutions. The regulatory aspect of financial sector support, encourages financial institutions and provides the necessary support.

The purchase of commercial papers of sufficient credit quality has as its main goal to expand the eligible collateral in its refinancing operations. The aim is to reinforce the actions the CB took to protect the flow of credit to companies and people. During April 2020, the CBs adopted packages of further easing measures to liquidity providing operations. ECB is making available up to $€ 3$ trillion in liquidity through its refinancing operations at the lowest interest rate ever offered, $-0.75 \%$. Offering funds below the ECB deposit facility rate allows for the amplifying of the stimulus from negative rates and for channeling it directly to those who can benefit most. European banking supervisors have also freed up an estimated $€ 120$ billion of extra bank capital, which can support considerable lending capa- city by euro area banks (ECB, 2020).

The response of the US FEDeral Reserve is reflected in a significant increase in liquid funds to save the economy and turned into purchases of government bonds by the FED, interest rates were reduced to zero and relied heavily on quantitative easing (QE). The FED has concluded foreign exchange agreements with nine foreign CBs to give them easier access to dollars in an effort to prevent a global economic shock due to the corona virus pandemic. The setup of swap line agreements have been concluded with the CBs of Brazil, Mexico, Australia, New Zealand, Denmark, Norway, Sweden, South Korea and Singapore. These measures, as well as those already established with other CBs, aim to reduce the pressure on world dollar financing markets and thus mitigate the effects of these tensions on household and corporate access to credit. Under these agreements the FED exchanges dollars for an equal amount of foreign currency. This allows foreign banks to provide dollars for their banks, which lend and trade in US dollars. Those banks will have access to a total of $\$ 450$ billion, which should ensure that the world's dollar-dependent financial system continues to function. The FED already has exchange agreements with the CBs of Canada, Great Britain, Japan, Switzerland and the ECB.

\section{MONETARY RESPONSE OF SELECTED CBS IN THE REGION}

In the above overview we recognise the determination of the world's largest financial systems for the application of unconventional economic policy measures in times of crisis. The policy of quantitative easing, is an attempt to achieve a recovery inflation rate and to stimulate economic growth, investment and employment. 
The pursuit of the ambitious economic recovery goals is based on a combined policy of low interest rates and the massive redemption of assets in the financial market, primarily government bonds. In a recession, the creators of the largest monetary systems have opted for a direct increase in money supply, which would stimulate aggregate demand by transmission mechanisms and initiate a set of positive effects on the economic and financial performance of the observed systems. The defined objectives have been achieved and the economic and financial system has been following a trend of positive growth and performance (Cvijanović, et al., 2019: 93).

\subsection{The National Bank of Serbia response}

The package of economic measures for the state to reduce the negative effects caused by the Covid-19 pandemic and support the Serbian economy involves a total of nine measures, with an estimated effect of RSD 608.3 billion. Of these nine, three are fiscal policy measures, two are direct assistance to the private sector and measures to preserve the liquidity of the economy, and other measures include a dividend moratorium by the end of the year and fiscal stimulus - that is, direct assistance to all adult citizens.

The National Bank of Serbia introduced Monetary Policy Measures to support the domestic economy and maintain the financial stability. The key policy rate was lowered to $1.75 \%$, the deposit facility rate to $0.75 \%$ and the lending facility rate to $2.75 \%$. Through April, the National Bank of Serbia trimmed the three main interest rates by an additional $0.25 \mathrm{pp}$ each, so that the key policy rate points at $1.50 \%$, the deposit facility rate at $0.50 \%$ and the lending facility rate at $2.50 \%$. The domestic financial sector was supplied with additional dinar and FX liquidity to sustain an unhindered flow of credit to local businesses and households. Through these measures the National Bank of Serbia gave an additional impulsion and support to the domestic financial system and economic flows. The above National Bank of Serbia measures provided additional liquidity to the banking system although it operated at excess liquidity even before that. Excess liquidity is now at its record high (National Bank of Serbia, 2020).

With the main goal to help the financial system in a new emergency situation and support the economy to withstand the financial shocks caused by the corona virus, the National Bank of Serbia decides to apply a moratorium on debt payment in the form of a decision on temporary measures for financial stability and temporary measures to save the national economy. The moratorium comprises all debtors who want to apply - companies, entrepreneurs, individuals, etc. in regards to suspension of debt payments for at least 90 days, or for the duration of the state of the COVID-19 pandemic.

During the mentioned period, debtors will be relieved of the repayment of their obligations under loan and lease agreements. However, even when these measures start to apply, borrowers and lessees will in no way be prevented from meeting their obligations on time. For the duration of the emergency state, banks and lessors will not charge any default interest on past due outstanding receivables and will not initiate enforcement or enforced collection procedures, or take other legal actions to collect receivables from their clients. Also, banks and lessors will not be able to charge any fees in relation to the application of the adopted regulations (National Bank of Serbia, 2020). 


\subsection{The Croatian National Bank measures}

Since beginning of March, the CNB has taken a number of measures in the field of monetary policy in order to maintain a liquidity and stability of the financial and macroeconomic system. The reserve requirement rate was reduced from $12 \%$ to $9 \%$, increasing banks' free means in the CNB. As a consequence of the coronavirus epidemic and the decline in economic activity, the CNB has also invested 31 billion HRK in the financial system to relax exchange rate pressures and to stabilise the national currency. In order to preserve stability in the government securities market, the CNB conducted three securities repurchase operations.

Table 2. Monetary policy measures of the CNB

\begin{tabular}{|c|c|c|}
\hline Objectives & Measures & Description \\
\hline $\begin{array}{l}\text { Stabilisation } \\
\text { of the foreign } \\
\text { exchange rate } \\
\text { and provision of } \\
\text { foreign currency } \\
\text { liquidity }\end{array}$ & $\begin{array}{l}\text { Foreign } \\
\text { Exchange } \\
\text { interventions }\end{array}$ & $\begin{array}{l}9 \text { - } 17 \text { March - four foreign exchange interventions at which a total of EUR } 1.625 \text { bn was } \\
\text { sold to banks } \\
\text { Exchange rate stabilised at around EUR/HRK } 7.57 \\
\text { Level of international reserves (total reserves at EUR 19.1bn;net reserves at EUR } 16.9 \mathrm{bn} \text {, } \\
\text { as at } 16 \text { March 2020) sufficient for further stabilisation }\end{array}$ \\
\hline $\begin{array}{l}\text { Provision of kuna } \\
\text { liquidity for the } \\
\text { ongoing financing } \\
\text { of the economy }\end{array}$ & $\begin{array}{l}\text { Structural } \\
\text { and regular } \\
\text { operations }\end{array}$ & $\begin{array}{l}16 \text { March } 2020 \text { - regular and structural operations; creation of HRK } 750 \mathrm{~m} \text { of short-term } \\
\text { liquidity and HRK } 3.8 \text { bn of long-term liquidity ( } 5 \text {-year maturity, interest rate of } 0.25 \% \text { ) } \\
\text { Daily liquidity surplus was HRK } 32.8 \text { bn as at } 16 \text { March } 2020\end{array}$ \\
\hline $\begin{array}{l}\text { Supporting the } \\
\text { stability of the } \\
\text { government bond } \\
\text { market }\end{array}$ & $\begin{array}{l}\text { Purchase of } \\
\text { government } \\
\text { bonds }\end{array}$ & $\begin{array}{l}\text { 13 March } 2020 \text { - the first auction for a direct purchase of Republic of Croatia bonds - } \\
\text { HRK } 211.2 \mathrm{~m} \text { purchased } \\
\text { the circle of counterparties that are entitled to participate in the purchase and sale of } \\
\text { securities has been expanded to include pension funds, companies for the management } \\
\text { of open-ended investment funds with a public offering and insurance companies } \\
\text { Announcement that auctions for the purchase of bonds will continue from } 18 \text { to } 23 \\
\text { March, expected purchase of another HRK } 1.6 \mathrm{bn}\end{array}$ \\
\hline
\end{tabular}

Source: adapted by the author, from Source: Croatian National Bank, Accessed on April 2020-04-11: https://www.hnb.hr/documents/20182/2953147/en170320_ prezentacija_Vujcic.pdf/a171cec8-b79d-a37d-61c9-ab85a1c858f8?t=1585210733912

ECB and CNB set up swap line to provide euro liquidity and to remain in place until the end of 2020, or as long as needed. A currency swap line is an agreement between two CBs to exchange currencies. This allows a $\mathrm{CB}$ to obtain foreign currency liquidity from the CB that issues it - usually because they need to provide this to domestic commercial banks. For example, the swap line with the US FEDeral Reserve System enables the ECB and all the national CBs in the euro area (Eurosystem) to receive US dollars from the FED in exchange for an equivalent amo- unt of euro provided to the FEDeral Reserve. These agreements have been part of CBs' set of monetary policy instruments for decades (ECB, 2020).

The CNB purchased securities of the Republic of Croatia in the nominal amount of HRK 9.529bn. The CNB will in due time inform the participants of any potential future fine-tuning operations-securities purchases. Reserve requirement rate reduced from $12 \%$ to $9 \%$ in order to release additional liquidity, which should allow the banking system and, consequently, the economy as a whole 
to cope more easily with the current crisis. A decrease in the reserve requirement rate will result in a reduction of the total reserve requirement by 10.45 billion, and the CNB surplus the allocated portion of the HRK obligatory reserve in the amount of HRK 6.33 billion will return HRK to banks on March 27, 2020. With this change in the reserve requirement rate, the $\mathrm{CNB}$ is also moving its minimum reserve system closer to the ECB's minimum reserve system, to which it will move with the introduction of the euro.

\subsection{CB of Bosnia and Herzegovina}

The primary task of monetary policy in countries undergoing transition and reform is to secure currency stability by keeping inflation at the lowest possible level. For a developing country in a transition, it is important to ensure macroeconomic stability which is a key condition for a stable national currency with a solid basis for the investments in economic development. A currency board was the only adequate form of monetary policy for the stabilisation of the financial sector in the political and economic environment characteristic for Bosnia and Herzegovina after the war. In terms of the achieved level of macroeconomic stability, we can say that the currency board arrangement in Bosnia and Herzegovina has achieved its main goal.

On the other hand, creating a favourable investment environment and a strengthening of a competitive position should represent the main goal of the $\mathrm{BiH}$ economy. In other words, meeting the macroeconomic stability is a good base for successful economic development in the long run. In conditions of passive monetary policy, the essential question for the $\mathrm{BiH}$ economy has been aimed at raising the international competitiveness of the country in order to reduce the current account deficit. If we observe the achieved level of macroeconomic stability and confidence in domestic currency, we can say that the currency board arrangement in Bosnia and Herzegovina has achieved its main goal. However, past experience and theoretical aspects of functioning of the currency board also show limitations in the results of growth of real investments, GDP and employment (Topić-Pavković, 2014: 232).

The issue of the effectiveness of the currency board as a monetary policy arrangement increases especially in times of crisis and shocks in the financial market. The opportunity to apply measures to help the economy and to get out of the crisis is limited and becomes a problem for the national economy. In the previous crisis in 2008, the CB of Bosnia and Herzegovina made a decision to reduce the reserve requirement rate on deposits that enter the reserve base, with a maturity of up to one year, from $14 \%$ to $10 \%$. The reserve requirement rate for deposits with a term longer than one year remains at $7 \%$. With this decision, additional liquid funds for commercial banks amounted to around BAM 300 million, which had an indirect effect on the liquidity of the real sector. This measure was justified given the fact it was a liquidity crisis. Significant amount of deposits and savings were withdrawn from banks due to panic, primarily by citizens, and banks were left without liquid funds for further investments. On the other hand, given the rigid arrangement of the currency board in $\mathrm{BiH}$, no other measure was available. The $\mathrm{BiH}$ currency board does not allow open market operations, therefore neither the purchase of corporate nor government bonds, which prohibits the monetisation of public debt. There is no function of lender of last resort, therefore, no credit extending to commercial banks. The $\mathrm{CB}$ of $\mathrm{BiH}$ has no development 
function, which includes lending to businesses. Therefore the question is, what measures are available to the $\mathrm{CBBH}$ in the pandemic crisis that emerged?

The accounts of the $\mathrm{CB}$ of Bosnia and Herzegovina $(\mathrm{CBBH})$ currently contain 5.5 billion BAM deposited by commercial banks and their depositors. Of these, 2.7 billion BAM is a required reserve, while 2.8 billion BAM represents a surplus above the required reserve. The $\mathrm{CBBH}$ has prescribed a uniform reserve requirement rate of $10 \%$, which it applies to the calculation base of required reserve. The $\mathrm{CBBH}$ is also entitled to specify compensation for excess of the reserve requirement. This fee was introduced in 2016, and is now negative, so since July 2016, the banks pay the $\mathrm{CB}$ of $\mathrm{BiH}$ a fee for the holding of money. The fee was reduced from - $0.2 \%$ (July 2016) to - 0.4\% (May 2019), and in September 2019 it was changed to $-0.5 \%$. The $\mathrm{CBBH}$ fee is equal to the fee charged by the ECB to its banks, and thus the $\mathrm{CBBH}$ follows one part of the monetary policy of the ECB. By deciding to introduce a negative interest rate on surplus amounts above the reserve requirement in the reserve accounts, the $\mathrm{CBBH}$ wants to encourage commercial banks to use these funds to provide loans to businesses and households. The surpluses above the commercial banks' reserve requirements on the $\mathrm{CBBH}$ 's reserve accounts have been continuously increasing for a long time, and currently amount to 2.8 billion BAM.

At the moment, in the crisis caused by the COVID-19 pandemic, $\mathrm{BiH}$ still has no problem with the larger withdrawal of funds from banks and these banks are liquid. If there was a significant drop in liquidity from banks, due to the withdrawal of deposits or savings, recommendation would be that the $\mathrm{CBBH}$ reduce the reserve rate and thereby release additional funds to banks.
There are several options for commercial banks in order to dispose their funds held in the CB. The first option for a commercial bank is to maintain the status quo. Within a year, the $\mathrm{CBBH}$ will calculate $0.5 \%$ of its surplus cash in excess of the reserve requirement. The second option is to convert the excess over the reserve requirement into foreign currency, which it then transfers to its account with a European bank in the form of a deposit. For this deposit amount, commercial banks will have neither yield nor earnings because interest rates abroad are negative. The possibility for commercial banks to reduce excess cash beyond the $\mathrm{CBBH}$ reserve requirement is to place loans at the lowest possible interest rate. Whatever the interest rate the bank sets and if it is greater than the CB of $-0.5 \%$, the commercial bank will make a profit, plus it will not pay the CB for a "deposit".

Another issue that increasingly appears is the portfolio of foreign exchange reserves of the CBBH. These are capital reserves that serve to amortize shocks that occur in the financial markets and to which we are exposed. The currency board policy requires that all money in circulation is covered by foreign currency reserves. In our case we are covered over $100 \%$ and this coverage is around $106 \%$, but this can change depending on the value of our foreign exchange reserves. Foreign exchange reserves are exposed to the financial market and are affected by changes occurring in this market. This means that the market value of foreign exchange reserves, which serves to cover money in circulation, changes daily. An example is the decrease in foreign exchange reserves since the beginning of the pandemic due to the volatility in the world financial markets.

As a result of the lower financial return on foreign currency reserve investments, as well as the consequence of the increase of the 
monetary liabilities of the $\mathrm{CB}$ of $\mathrm{BiH}$ and the corresponding increase of the CBBH's net foreign exchange reserves, the ratio of convertible mark to Euro declines. The convertible mark must be covered by a minimum of $100 \%$ foreign exchange, but precisely because of market distortions, for the caution, it must be at least $105 \%$. The convertible marks to Euro ratio declines due to market movements.

The $\mathrm{CB}$ of $\mathrm{BiH}$ law clearly indicates that the CB invests foreign assets in accordance with the principles and practice of sound investment and only in liquid securities issued by the country in whose currency the securities are denominated. From an economic or profit point of view, the reserves must be invested in a safe, liquid and profitable way. Safe means investing in investable securities (credit rating better than $\mathrm{BBB}+$ ), liquid instruments, which means that they can be converted immediately to cash when needed. It should be noted that the eventual conversion of the $\mathrm{CB}$ of $\mathrm{BiH}$ into an issuing bank would probably entail amendments to the Law on the CB leaving the currency board and allowing the CB to pursue an autonomous monetary policy. To make decisions of this type would be to change the law entirely and to make some other rules concerning the management of reserves in relation to the practices, laws and regulations currently in use.

The Banking Agency of the Republic of Srpska adopted the decision on temporary measures of banks to mitigate the negative economic consequences caused by the COVID-19 virus. Having in mind the necessity of stability and security of the Republic of Srpska banking system in emergency conditions, the decisions refer to granting relief to bank clients who are directly or indirectly affected by negative effects, as well as special rules for credit risk management. The special measures to the client and preventive measu- res aimed at preserving the capital of banks. The measures specified by the RS Banking Agency, which concern special measures to facilitate loan repayment, do not apply to all clients and banks will decide on the provision of benefits on a case-by-case basis. These measures may be: a moratorium, as a deferral of repayment of principal and interest on loans, which may last at least until the end of the state of emergency; introduction of a grace period for repayment of the principal of credit obligations for a period of 6 months maximum; granting an additional amount of exposure for the purpose of overcoming its current liquidity difficulties and other measures aimed at facilitating the settlement of the client's credit obligations and maintaining the client's business. Deferred payment of the loan installment has been recognised as an acceptable measure to alleviate monthly liabilities to those legal and natural persons whose creditworthiness has deteriorated, i.e. whose sources of repayment have been reduced and thus the settlement of liabilities to the bank has been or will be prevented.

Banks may initiate a moratorium and other special measures on their own initiative as part of the regular process of monitoring receivables in arrears if the client is affected by the negative effects of extraordinary circumstances. In this process, a decision is made on the modality that is most appropriate for resolving the new situation, and specifically the moratorium is approved with the maximum duration until the abolition of the declaration of a state of emergency. 
5. THE DISCUSSION OF COMPARATIVE ANALYSIS BETWEEN CBS REACTIONS TO CRISIS

In most countries, the primary goal of monetary policy is to maintain price stability through a low inflation rate. Although most CBs pursue prudent monetary policies, monetary authorities must consider the influence of its measures in economic crisis and market shocks. What started as a shock to the health sector in the beginning of 2020 has quickly become an economic crisis that has engendered both a supply and a demand shock. The COVID-19 pandemic requires reactions combining expansive fiscal and monetary policies to alleviate the impending recession. Countries have announced discretionary changes in their fiscal and monetary policies in an attempt to reduce the economic consequences of the pandemic. These discretionary changes are mostly related to the introduction of tax relief, raising the level of government spending and public borrowing (fiscal expansion), as well as lowering interest rates (monetary expansion).

After the outbreak of the global financial crisis in 2008 and its intensification in the following years, we witnessed a redefinition of the role of the CB. The most important change concerned the expansion of the list of objectives for the realisation of which the CB is responsible. Price stability remains the primary goal, but CBs are expected to pay almost equal attention to preserving and strengthening financial stability. Thus, the function of conducting macroeconomic policy is added to the traditional functions.

An overview of the measures and activities taken by the CBs in order to support national economies affected by COVID-19 clearly shows the importance of policy mix strategy, especially in times of crisis. Fiscal policy measures have been taken on time in most countries and are more evident in the short term. Monetary policy measures, conditioned primarily by the transmission mechanism and the length of transformation into concrete results are still to be recognised. The challenges of the crisis also imposed changes in the area of instruments. In addition to standard instruments, $\mathrm{CBs}$ respond to the challenges of the crisis by introducing non-standard (unconventional) monetary policy instruments.

Based on the analysis, it can be concluded that the CBs of the largest economies applied measures of quantitative easing policy to contribute to the recovery of their national economies. Quantitative easing relies on the purchase of available liquidity, that is, various forms of securities by the $\mathrm{CB}$. The purchase of securities lowers market interest rates and encourages investments in riskier financial assets, reduces the cost of financing and refinancing loans and aims to increase the competitiveness of exports by creating depreciation currency pressures. The pursuit of the ambitious economic recovery goals is based on a combined policy of low interest rates and the massive redemption of assets in the financial market, primarily government bonds. The open questions of the effectiveness of quantitative easing policies, concerns potential negative effects in the context of the redistribution of wealth and the impact of transmission mechanisms on investor returns and individual earnings. A particular issue, in terms of stabilised performance for all monetary systems that applied unconventional measures, is the monetary policymakers' further steps, as extreme increases in money supply carry the risk of potential inflation shocks and hyperinflation.

In times of great uncertainty, customers' demand for foreign currency assets can incre- 
ase. If banks do not have enough foreign currency reserves on hand to meet increased demand, markets can become unstable. So CBs have established so-called currency swap lines. These swap lines let CBs of one country exchange their national currency reserves for those of the $\mathrm{CB}$ of another country - thus ensuring that $\mathrm{CBs}$ can meet the increased demand. We can identify swap lines as one of the CBs measures across the globe in response to the current difficult situation (ECB, 2020). Accordingly, from all the above, it is obvious that the economic policies (fiscal and monetary) of different countries vary in relation to: the degree of virus transmission, the range of prevention measures (from social distancing to mandatory movement bans), health system preparedness, financial capacity and efficiency of state institutions.

The coronavirus pandemic poses the most serious threat to the $\mathrm{BiH}$ economy since the global financial crisis. Slower growth in the Euro zone, the largest $\mathrm{BiH}$ export market, and regional trade disputes contributed to a fall in exports, as did a slump in industrial production, resulting in part from temporary output disruptions at large exporting firms. More recent data for Q1 2020 indicate a sharp broad-based slowdown of economic activity as a result of the current pandemic. The financial sector is expected to remain stable even with COVID-19. Credit growth has been positive and accelerating in 2019, with lending growing faster to households than to businesses. Most banks are sufficiently capitalised, liquid, and profitable but the performance of foreign-owned and domestic banks differs (World Bank, 2020).

Financial aspect of short-term measures in mitigating the social and economic impact of COVID-19 in $\mathrm{BiH}$, is best manifested through Banking Agencies actions. The six-month loan repayment moratorium is introduced as a form of credit arrangements in order to help individuals and legal entities who are the most affected by the COVID-19 pandemic. The goal is to unburden them from obligations for those months when they had no income. Given the rigid and passive monetary policy in $\mathrm{BiH}$, the unavailability of adequate instruments represents a limitation of the effectiveness of overall economic policy measures. Therefore, the question is how appropriate this form of monetary policy arrangement is in times of crisis and external shocks.

\section{CONCLUSION}

The majority of CBs are traditionally focused on goals in preserving financial and macroeconomic stability. However, in the conditions of extraordinary circumstances that have led to a rapid decline in the most important economic parameters around the world, the focus has shifted to maintaining the purchasing power of the population and the sustainable supply of economic entities. The specificity of the pandemic is reflected in the symmetrical shock of the market, which simultaneously hit the supply and demand side, provoking at the same time reactions from $\mathrm{CBs}$ as the bearers of monetary authorities.

Facilitating accessibility to credit funds for companies and households is achieved with an increased amount of money banks can borrow from CBs. That makes borrowing easier, especially for those who are heavily hit by the spread of the virus. The collateral that banks give as a form of insurance to $\mathrm{CBs}$, are now extended and less strict. The banks are given more flexibility on supervisory timelines, deadlines and procedures. In the final review, the purpose of involving CBs is to help the economy and society to more 
easily overcome the consequences caused by the pandemic.

It can be concluded that the measures proposed by the countries are a combination of measures to support the economy and provide liquidity on the one hand, and certain measures of social assistance on the other hand. As such, the measures are based on policy-mix comprehensiveness, and their success in combating the effects of the recession will depend on timely and effective implementation, as well as on the duration of the virus crisis.

\section{REFERENCE}

Ayuso, J., \& Repullo, R. (2003). A Model of the Open Market Operations of the ECB. Economic Journal, 113 (490), 883-902. Retrieved 11.03.2020. URL: https://econpapers.repec. org/scripts/showcites.pf?h=repec:ecj:econjl:v:113:y:2003:i:490:p:883-902

Bindseil, U., \& Nyborg, K. (2008). Monetary policy implementation. Discussion Paper Series of the Norwegian School of Economics and Business Administration. Retrieved 18.04. 2020. URL: https://www.ecb.europa.eu/ pub/pdf/scpwps/ecbwp1052.pdf

Blanchard, O., Dell'Ariccia, G., \& Mauro, P. (2014). Rethinking Monetary Policy, IMF Staff Position Note, SBP/10/03. Retrieved 21.03.2020. URL: https://www.imf.org/external/pubs/ft/ spn/2010/spn1003.pdf

Cvijanović, D., Vojinović, Ž., \& Živković, S. (2019). Kvantitativno popuštanje Evropske centralne banke. Časopis Ekonomskog fakulteta Brčko, Vol. 13, Sveska 1, str. 85-93. DOI: 10.7251/ZREFB1913085C

Fecht, F., Nyborg, K. G., \& Rocholl, J. (2008).
The price of liquidity: Bank characteristics and market conditions. Working paper series No 1376. Retrieved 19.03.2020. URL: https://www.ecb.europa.eu/pub/pdf/scpwps/ ecbwp1376.pdf

Gambetti L., \& Musso, A. (2017). The macroeconomic impact of the ECBs expanded asset purchase programme (APP). ECB, Working paper series No. 2075. Retrieved: https://www. ecb.europa.eu/home/html/index.en.html

Ho, C. (2008). Implementing monetary policy in the 2000s: operating procedures in Asia and beyond. BIS Working paper series No. 253. Retrieved 19.03.2020. https://www.bis. org/publ/work253.htm

Joyce, M., Miles, D., Scott, A., \& Vayanos, D. (2012). Quantitative Easing and Unconventional Monetary Policy - An Introduction. The Economic Journal. Retrieved 08. 05. 2020. URL: https://www.researchgate. net/publication/256038514_Quantitative_ Easing_and_Unconventional_Monetary_ Policy_-_An_Introduction

Meade, E., Nozawa, Y., Petrasek, L. \& Zickler, J. (2015). The effects of FOMC communications before policy tightening in 1994 and 2004, Technical report, FEDS Notes. Washington: Board of Governors of the FEDeral Reserve System. Retrieved 19. 04.2020. URL: https://www.FEDeralreserve.gov/ econresdata/notes/FEDs-notes/2015/effects-of-fomc-communications-before-policy-tightening-in-1994-and-2004-20150924. html

Nakashima, K., Shibamoto, M. \& Takahashi, K. (2017). Risk-taking channel of unconventional monetary policies in bank lending. Kobe University Discussion Paper Series, No. 
24. Retrieved 10. 05.2020. URL: https://www. rieb.kobe-u.ac.jp/academic/ra/dp/English/ DP2017-24.pdf

Potter, S., \& Smets, F. (2019). Unconventional monetary policy tools: a cross-country analysis. Report prepared by a Working Group by FEDeral Reserve Bank of New York and ECB. Retrieved 20. 04. 2020. URL: https://www.bis.org/publ/cgfs63.pdf

Sellin, P., \& Sommar, P. A. (2014). The Riksbank's operational framework for the implementation of monetary policy-a review. Sveriges Riksbank Report. Retrieved 15. 04. 2020. URL: http://archive.riksbank.se/Documents/Rapporter/Riksbanksstudie/2014/rap_ riksbanksstudie_140326_eng.pdf

Topić-Pavković, B. (2014). Mogući pravci razvoja monetarne politike Bosne i Hercegovine u cilju podsticanja ekonomskog rasta. Acta Economica, 12(20), 213-241.

ECB (2020). ECB takes steps to mitigate impact of possible rating downgrades on collateral availability. Retrieved 15. 05. 2020.
URL: https://www.ecb.europa.eu/press/pr/ date/2020/html/ecb.pr200422_1 95e0f62a2b. en.html

National Bank of Serbia (2020). Response to COVID-19. Retrieved 10. 05. 2020. URL:

https://www.National Bank of Serbia.rs / internet/english/15/Covid19/index.html

Croatian National Bank (2020). CNB's response to COVID-19 crisis. Retrieved 10.05.2020. URL: https://www.hnb.hr/-/ odgovor-hnb-a-na-covid-19-krizu

CB of Bosnia and Herzegovina (2020). Monetary and Financial System in Bosnia and Herzegovina. Retrieved 10.05.2020. URL: https:// www.cbbh.ba/press/ShowNews/1241

The World Bank. (2020). The Economic and Social Impact of COVID-19: Western Balkans Outlook - 9. Retrieved 18.05.2020. URL: http://documents.worldbank.org/curated/ en/606131588087679463/The-Economicand-Social-Impact-of-COVID-19-Western-Balkans-Outlook 


\section{ODGOVOR CENTRALNIH BANKA NA PANDEMIJU KOVID-19}

\begin{abstract}
Ključne riječi:
centralna banka; monetarna politika; korona virus; kriza izazvana pandemijom
\end{abstract}

Autor:

Dr Branka Topić-Pavković je docent na Ekonomskom fakultetu Univerziteta u Banjoj Luci

Korespodencija: branka.topic-pavkovic@ ef.unibl.org

Oblast:

Fiskalna i monetarna ekonomija

DOI:

10.5937/politeia0-26720

Datum prijema članka: 23.05.2020.

Datum prihvatanja članka za objavljivanje:

\section{Rezime}

Uposljednjih nekoliko mjeseci svijet se bori protiv nevidlivivg neprijatelja koji utiče na sve aspekte života sa istovremenim ekonomskim, humanitarnim i socijalnim posljedicama. $U$ ovom trenutku, ekonomske posljedice krize izazvane virusom korona su još uvijek većim dijelom nepoznanica, ali činjenica je da će najvea kriza u novijoj istoriji izazvana pandemijom dovesti do globalne recesije. U vrijeme krize, strategija zemalja u primjeni kombinacije monetarne $i$ fiskalne politike je neophodna i podrazumijeva uključivanje centralnih banaka $u$ obezbjedivanje adekvatnih mjera monetarne politike za ekonomski i finansijski oporavak.

Cilj ovog rada je identifikovati $i$ analizirati mjere koje su preduzele centralne banke kako bi ublažile štetu uzrokovanu pandemijom i pomogle nacionalnim ekonomijama u oporavku. Ponovno aktiviranje nestandardnih mjera monetarne politike primenjenih i u prethodnoj finansijskoj krizi iz 2008. godine, pokazuje da su standardni instrumenti i ciljevi CB nedovoljni u vanrednim okolnostima. Provedena komparativna analiza pokazaće kako su centralne banke najvećih ekonomija kao i zemalja regiona odgovorile na izazov virusa korone, a sa posebnim osvrtom na Centralnu banku Bosne i Hercegovine.

Rezultati pokazuju da su se centralne banke odlučile za nekonvencionalne mjere monetarne politike koje se prvenstveno ogledaju u mjerama kvantitativnog popuštanja, veoma niskih kamatnih stopa i uvođenje svop linija kako bi ublažile negativne efekte nastale krize. Biće potrebne izuzetne mjere kako bi se osigurao oporavak od brzog pogoršanja globalne ekonomije. Specifičnost monetarnog aranžmana u Bosni i Hercegovini još jednom se pokazao kao ograničenje u sprovođenju mjera ekonomske politike u vanrednim okolnostima. 
